\title{
Hypertext Archive of the Tropics
}

\author{
compiled by Stephen Torre
}

From the first emergence of geographical models which postulated a warm tropical zone between the two hemispheres, philosophers, theologians, and thinkers of all kinds have speculated on what might be found in the tropics and about the equator. When eventually mariners, navigators and explorers opened up this zone to naturalists and travelers, fantastic accounts and descriptions of the tropics proliferated. The area was described as both an Arcadian paradise where beautiful animals lived in harmony with human beings, and an infernal dystopia of monstrous beasts and polygamous savages and cannibals. In places the tropics could be a desert of barrenness and infertility or an expanse of featureless ocean, while elsewhere it was an aquarium of exotica or a fecund forest of immense biodiversity. For naturalists and scientists it became a vast laboratory in which modern geological, zoological and evolutionary theories were incubated. For imperialists and businessmen it was a cornucopia of precious metals, plantations, and profit.

This work is the first version of an archive of writings about the tropics, to be expanded in future issues of etropic. Readers' suggestions are most welcome and contributors of extracts will be acknowledged. The entries are arranged chronologically, but a hypertext author index is included, and this will be supplemented by subject search engines as the archive expands.

\section{Mandeville's Travels in the Tropics}

Mandeville's Travels was one of the most popular works of the fourteenth century. Framed as the autobiography of a traveller, the knight Sir John Mandeville "that was born in England in the town of St. Albans", scholars now believe that Mandeville was probably not an Englishman but a native of Liège, and that his book was written in French in about 1357. Furthermore his adventures in Europe, Africa, and Asia, were most likely based on accounts by other travellers. 'Mandeville' interpolated lengthy extracts from a range of medieval writings, drawing particluarly on the genuine observations of Haiton (an Armenian nobleman c. 1308) for his accounts of the East. Mandeville's hybird text is thus a fascinating insight into the medieval understanding of the world, and in particular the tropics. 
Two chapters deal with the tropics: Chapter 20, "Of the evil customs used in the isle of Sumatra. And how the earth and the sea be of round form and shape by proof of the star that is cleped Antarctic, and is fixed in the south" and Chapter 21, "Of the palace of the king of the isle of Java. Of the trees that bear meal, honey, wine, and venom. And of other marvels and customs used in the isles marching thereabout".

In Chapter 20 Mandeville relates how the natives of Sumatra go naked, and (curiously) defend their custom in Christian terms:

In that land is full great heat. And the custom there is such that men and women go all naked, and they scorn when they see any strange folk going clothed. And they say that God made Adam and Eve all naked, and that no man should shame him to show him such as God made him, for nothing is foul that is of kindly nature.

The question of marriage and monogamy also gets a Western theological defence:

And they wed there no wives, for all the women there be common and they forsake no man. And they say they sin if they refuse any man. And so God commanded to Adam and Eve and to all that come of him when He said, Crescite et multiplicamini et replete terram. And therefore may no man in that country say, "This is my wife,"nor no woman may say, "This is mine husband."And when they have children, they may give them to what man they will that hath companied with them.

The picture so far presented of this land, where "al the land is common [and] also all the goods of the land be common, corns and all other things" is, so far, utopian. The fourth paragraph of the chapter dispels this picture:

But in that country there is a cursed custom, for they eat more gladly man's flesh than any other flesh. And yet in that country abundant of flesh, of fish, of corns, of gold and silver, and of all other goods. Thither go merchants and bring with them children to sell to them of the country, and they buy them. And if they be fat they eat them anon. And if they be lean, they feed them till they be fat and then they eat them. And they say that it is the best flesh and the sweetest of all the world."

Mandeville's Travels. Ed. M.C. Seymour. London: OUP, 1968. Originally published c. 1357 


\section{A Promise of Gold and Silver}

During the sixteenth century and later many European expeditions sought for a legendary land of gold and plenty known as El Dorado. The name (Spanish for 'the gilded man') referred to a ritual of the Chibcha tribe of Colombia. Annually, a leader was chosen and painted with gold. The leader would then enter a sacred lake and ceremoniouusly wash off the gold, also casting other valuable offerings of emeralds and gold into the lake. In the following account, Sir Walter Ralegh believes he has come close to discovering El Dorado in Guiana, during his first expedition to the area in 1595.

When we ran to the tops of the hills of the plains adjoining to the river, we beheld that wonderful breach of waters, which ran down Caroli: and might from that mountain wee the river how it ran in three parts, above twenty miles off, and there appeared some ten or twelve overfalls in sight, every one as high over the other as a church-tower, which fell with that fury that the rebound of waters made it seem as if it had been all covered over with a great shower of rain: and in some places we took it at the first for a smoke that had risen over some great town. For mine own part, I was well persuaded from thence to have returned, being a very ill footman, but the rest were all so desirous to go near the said strange thunder of waters, as they drew me on by little and little, till we came into the next valley, where we might better discern the same. I never saw a more beautiful country, nor more lively prospects, hills so raised here and there over the valleys, the river winding into divers branches, the plains adjoining without bush or stubble, all fair green grass, the ground of hard sand easy to march on, either for horse or foot, the deer crossing in every path, the birds towards the evening singing on every tree with a thousand several tunes, cranes and herons of white, crimson, and carnation perching on the river's side, the air fresh with a gentle easterly wind, and every stone that we stooped to take up, promised either gold or silver by his complexion.

Sir Walter Ralegh (1552?-1618), The Discovery of the Large, Rich and Beautiful Empire of Guiana (1596)

\section{On the Heat in Africa}


"I call it hot, when a man sweats at rest, and excessively on moderate motion. I call it very hot, when a man, with thin or little clothing, sweats much, thought at rest. I call it excessive hot, when a man in his shirt, at rest, sweats excessively, when all motion is painful, and tghe kness feel feeble, as if after a fever. I call it extreme hot, when the strenght fails, a disposition to faint comes on, a straitness is found round the temples, as if a small cord were drawn round the head, the voice impaired, the skin dry, and the head seems more than ordinary large and light. This, I apprehend, denotes death at hand."

James Bruce (1730-1794), Travels to Discover the Source of the Nile (1790)

\section{Tropical Hallucinations}

In Confessions of an English Opium-Eater, De Quincey gives an account of how he became addicted to laudanum, the often terrifying visions he experienced as a result of it's effect, and how he gradually reduced the dose from 8,000 drops a day, suffering great withdrawal symptoms.

"Under the connecting feeling of tropical heat and vertical sunlight, I brought together all creatures, birdss, beasts, reptiles, all trees and plants, usages and appearances, that are found in all tropical regions, and assembled them together in China or Hindostan. From kindred feelings, I soon brought Egypt and her gods under the same law. I was stared at, hooted at, grinned at, chatted at, by monkeys, by paroquets, by cockatoos. I ran into pagodas, and was fixed for centuries at the summit, or in secret rooms; I was the idol; I was the priest; I was worshipped; I was sacrificed. I fled from the wrath of Brama through all the forests of Asia; Vishnu hated me; Seeva lay in wait for me. I came suddenly upon Isis and Osiris: I had done a deed, they said, which the ibis and the crocodile trembled at. Thousands of years I lived and was buried in stone coffins, with mummies and sphinxes, in narrow chambers at the heart of eternal pyramids. I was kissed, with cancerous kisses, by crocodiles, and was laid, confounded with all unutterable abortions, amongst reeds and Nilotic mud."

Thomas De Quincey (1785-1859), from Confessions of an English Opium-Eater (1822) 


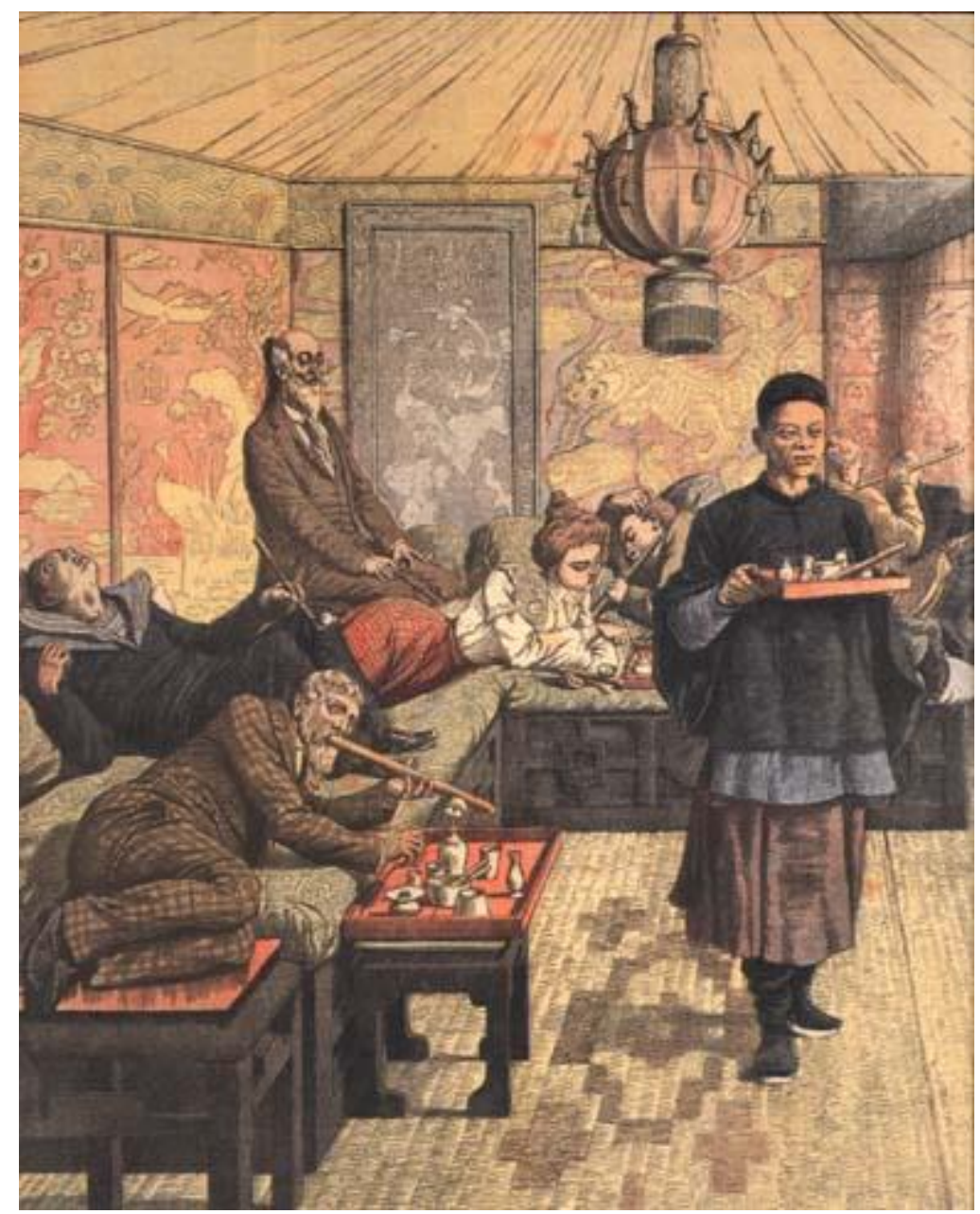

\section{Aborigines, Kangaroos and Coral Reefs}

In 1770 Captain James Cook mapped the Australian coastline from Botany Bay north to Cape York. On the evening of 11 June somewhere near Cape Tribulation on the East coast of northern Australia, the Endeavour struck the Great Barrier Reef with serious damage to the hull. Fighting difficult weather and unusual king tides every effort was made to refloat the vessel. (The following extracts are abridged and condensed selections from the Endeavour Journal of Joseph Banks.) 


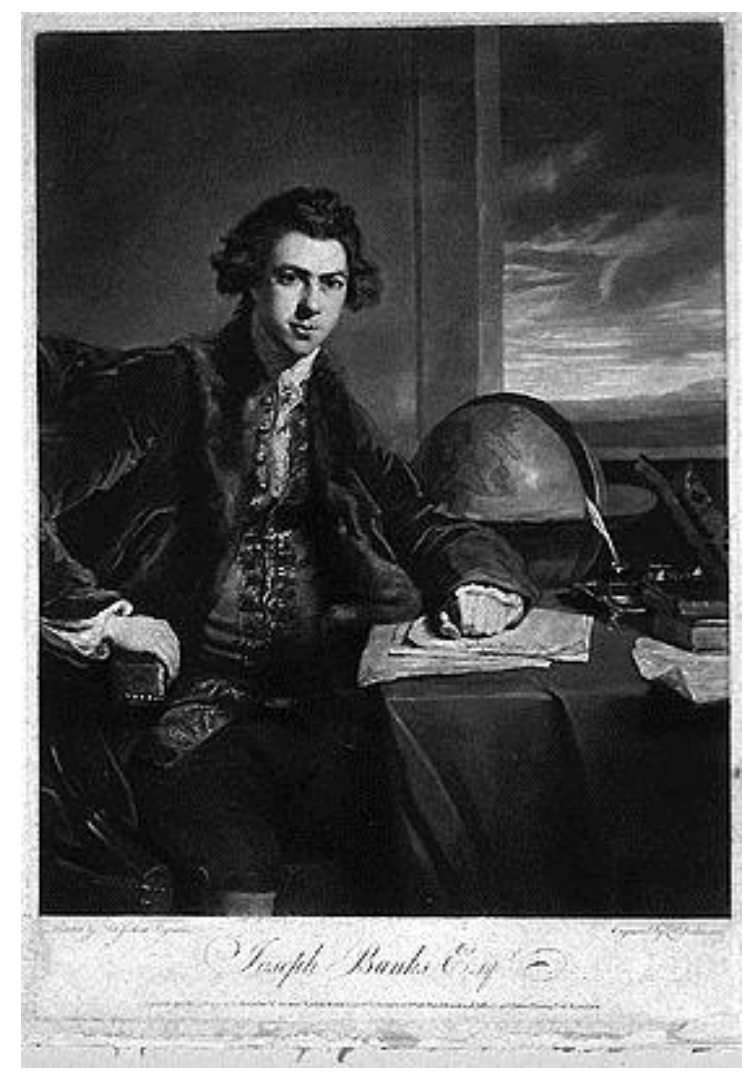

\section{Sir Joseph Banks}

\section{Running Aground}

Just without us as we lay at an anchor was a small sandy Island laying upon a large Coral shoal, much resembling the low Islands to the eastward of us but the first of the kind we had met with in this part of the South Sea. Early in the morn we weighd and saild as usual with a fine breeze along shore, the Countrey hilly and stoney. At night fall rocks and sholes were seen ahead, on which the ship was put upon a wind off shore. While we were at supper she went over a bank of 7 or 8 fathom water which she came upon very suddenly; this we concluded to be the tail of the Sholes we had seen at sunset and therefore went to bed in perfect security, but scarce were we warm in our beds when we were calld up with the alarming news of the ship being fast ashore upon a rock, which she in a few moments convincd us of by beating very violently against the rocks. Our situation became now greatly alarming: we had stood off shore 3 hours and a half with a plesant breeze so knew we could not be very near it: we were little less than certain that we were upon sunken coral rocks, the most dreadfull of all others on account of their sharp points and grinding quality which cut through a ships bottom almost immediately. The officers however behavd with inimitable coolness void of all hurry and confusion; a boat was got out in which the master went and 
after sounding round the ship found that she had ran over a rock and consequently had Shole water all round her. All this time she continued to beat very much so that we could hardly keep our legs upon the Quarter deck; by the light of the moon we could see her sheathing boards \&c. floating thick round her; about 12 her false keel came away. [...]

Orders were now given for lightning the ship which was began by starting our water and pumping it up; the ballast was then got up and thrown over board, as well as 6 of our guns (all that we had upon deck). All this time the Seamen workd with surprizing chearfullness and alacrity; no grumbling or growling was to be heard throughout the ship, no not even an oath (tho the ship in general was as well furnishd with them as most in his majesties service). About one the water was faln so low that the Pinnace touchd ground as he lay under the ships bows ready to take in an anchor, after this the tide began to rise and as it rose the ship workd violently upon the rocks so that by 2 she began to make water and increasd very fast. At night the tide almost floated her but she made water so fast that three pumps hard workd could but just keep her clear and the 4th absolutely refusd to deliver a drop of water. Now in my own opinion I intirely gave up the ship and packing up what I thought I might save prepard myself for the worst.[...]

The dreadfull time now aproachd and the anziety in every bodys countenance was visible enough: the Capstan and Windlace were mannd and they began to heave: fear of Death now stard us in the face; hopes we had none but of being able to keep the ship afloat till we could run her ashore on some part of the main where out of her materials we might build a vessel large enough to carry us to the East Indies. At 10 o'clock she floated and was in a few minutes hawld into deep water where to our great satisfaction she made no more water than she had done, which was indeed full as much as we could manage tho no one there was in the ship but who willingly exerted his utmost strength. [...]

During the whole time of this distress I must say for the credit of our people that I beleive every man exerted his utmost for the preservation of the ship, contrary to what I have universaly heard to be the behavior of sea men who have commonly as soon as a ship is in a desperate situation began to plunder and refuse all command. This was no doubt owing intirely to the cool and steady conduct of the officers, who during the whole time never gave an order which did not shew them to be perfectly composd and unmovd by the circumstances howsoever dreadfull they might appear. 


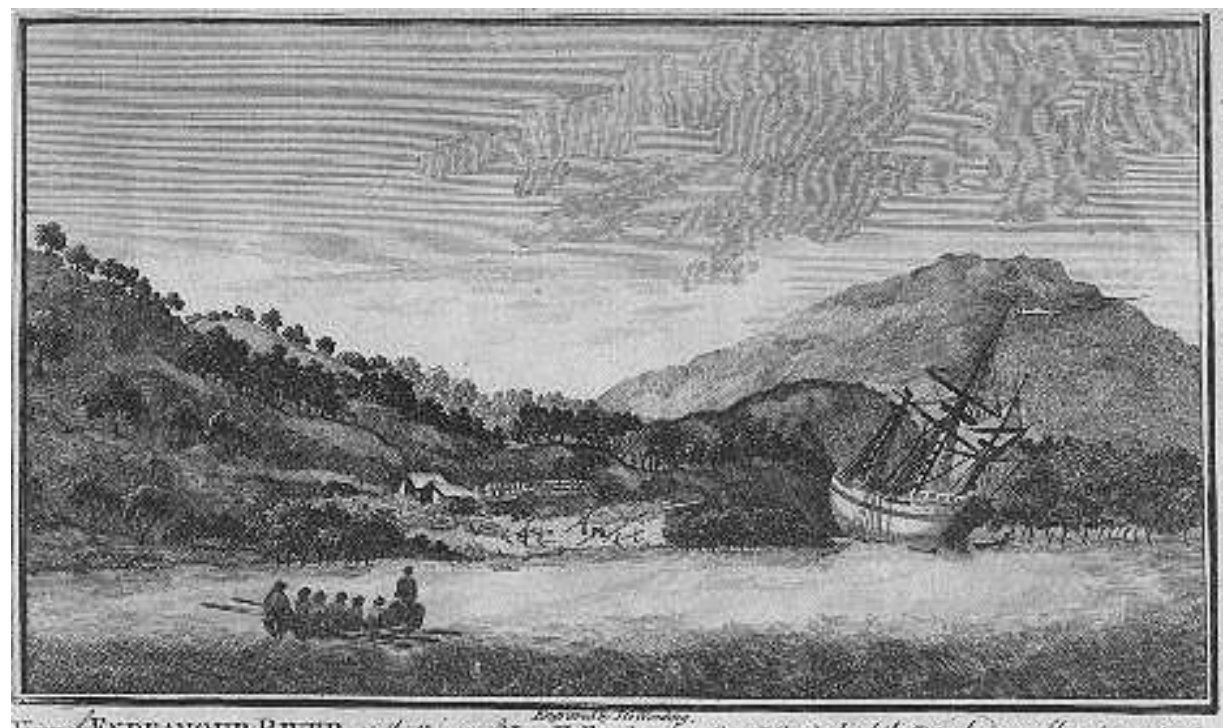

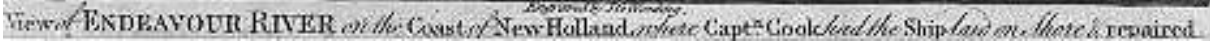

\section{Catching a Kangaroo}

It took five days to maneuver the bark through shoals to a landing in the EndeavourRiver, near present day Cooktown, on the 16 June. Repairs were carried out and the expedition finally left the Endeavour River on the 4 August. During this time Banks and his colleagues explored the fauna and flora of the area. After sighting a strange animal (a kangaroo) several times, one was eventually shot and eaten.

Went over the Water today to spy the land which there was sand hills. On them I saw some Indian houses which seem'd to have been inhabited since those on this side, tho not very lately. There were vast flocks of Pigeons and crows; of the former which were very beautifull we shot several; the latter exactly like those in England were so shy that we could not come near them by any means. The Inlet or river in which we lay ran very far into the countrey, keeping its course over flat land overgrown with Mangroves; the countrey inland was however sufficiently hilly. Evening hard rain. [...]

Gathering plants and hearing descriptions of the animal which is now seen by every body. A seaman who had been out in the woods brought home the description of an animal he had seen composd in so Seamanlike a stile that I cannot help mentioning it: it was (says he) about as large and much like a one gallon cagg, as black as the Devil and had 2 horns on its head, it went but Slowly but I dard not touch it.

In gathering plants today I myself had the good fortune to see the beast so much talkd of, tho but imperfectly; he was not only like a grey hound in size and running but had a long tail, as 
long as any grey hounds; what to liken him to I could not tell, nothing certainly that I have seen at all resembles him. [...]

Set out today with the second lieutenant resolvd to go a good way up the river and see if the countrey inland differd from that near the shore. We went for about 3 leagues among Mangroves, then we got into the countrey which differd very little from what we had seen. From hence we proceeded up the river which contracted itself much and lost most of its mangroves; the Banks were steep and coverd with trees of a Beautifull verdure particularly what is calld in the West Indies Mohoe or Bark tree (Hibiscus tiliaceus); the land within was generaly low, coverd thick with long grass, and seemd to promise great fertility were these people to plant and improve it. In the course of the Day Tupia saw a Wolf, so at least I guess by his description, and we saw 3 of the animals of the countrey but could not get one; also a kind of Batts as large as a Partridge but these also we were not lucky enough to get. At night we took up our lodgins close to the banks of the river and made a fire, but the Musquetos, whose peacefull dominions it seems we had invaded, spard no pains to molest us as much as was in their Power: they followd us into the very smoak, nay almost into the fire, which hot as the Climate was we could better bear the heat of than their intolerable stings.

Between the hardness of our beds, the heat of the fire and the stings of these indefatigable insects the night was not spent so agreably but that day was earnestly wishd for by all of us; at last it came and with its first dawn we set out in search of Game. We walkd many miles over the flats and saw 4 of the animals, 2 of which my greyhound fairly chas'd, but they beat him owing to the lengh and thickness of the grass which prevented him from running while they at every bound leapd over the tops of it. We observd much to our surprize that instead of Going upon all fours this animal went only upon two legs, making vast bounds just as the Jerbua (Mus Jaculus) does. [...]

At day light in the Morn the tide serving we set out for the ship. In our passage down met several flocks of Whistling Ducks of which we shot some; we saw also an Allegator of about 7 feet long come out of the Mangroves and crawl into the Water. [...]

Our second lieutenant who was a shooting today had the good fortune to kill the animal that had so long been the subject of our speculations. To compare it to any European animal would be impossible as it has not the least resemblance of any one I have seen. Its fore legs are extreemly short and of no use to it in walking, its hind again as disproportionaly long; 
with these it hops 7 or 8 feet at each hop in the same manner as the Gerbua, to which animal indeed it bears much resemblance except in Size, this being in weight $38 \mathrm{lb}$ and the Gerbua no larger than a common rat.

The Beast which was killd yesterday was today Dressd for our dinners and provd excellent meat. In the evening the Boat returnd from the reef bringing 4 Turtles, so we may now be said to swim in Plenty. Our Turtles are certainly far preferable to any I have eat in England, which must proceed from their being eat fresh from the sea before they have either wasted away their fat, or by unatural food which is given them in the tubs where they are kept given themselves a fat of not so delicious a flavour as it is in their wild state. Most of those we have caught have been green turtle from 2 to $300 \mathrm{lb}$ weight: these when killd were always found to be full of Turtle Grass (a kind of Conferva I beleive); two only were Loggerheads which were but indifferent meat; in their stomachs were nothing but shells.

\section{Meeting the Guggu Yimithirr}

During the excursion Banks and his team made contact with some aborigines of the Guggu Yimithirr tribe, whom he was able to observe at close quarter.

Four Indians appeard on the opposite shore; they had with them a Canoe made of wood with an outrigger in which two of them embarkd and came towards the ship but stop'd at the distance of a long Musquet shot, talking much and very loud to us. We hollowd to them and waving made them all the signs we could to come nearer; by degrees they venturd almost insensibly nearer and nearer till they were quite along side, often holding up their Lances as if to shew us that if we usd them ill they had weapons and would return our attack. Cloth, Nails, Paper, \&c \&c. was given to them all which they took and put into the canoe without shewing the least signs of satisfaction: at last a small fish was by accident thrown to them on which they expressd the greatest joy imaginable, and instantly putting off from the ship made signs that they would bring over their comrades, which they very soon did and all four landed near us, each carrying in his hand 2 Lances and his stick to throw them with. Tupia went towards [them]; they stood all in a row in the attitude of throwing their Lances; he made signs that they should lay them down and come forward without them; this they immediately did and sat down with him upon the ground. We then came up to them and made them presents of Beads, Cloth \&c. which they took and soon became very easy, only Jealous if any one attempted to go between them and their arms. At dinner time we made signs to them to come 
with us and eat but they refusd; we left them and they going into their Canoe padled back to where they came from. [...]

Indians came again today and venturd down to Tupias Tent, where they were so well pleasd with their reception that three staid while the fourth went with the Canoe to fetch two new ones; they introduc'd their strangers (which they always made a point of doing) by name and had some fish given them. They receivd it with indifference, signd to our people to cook it for them, which was done, and they eat part and gave the rest to my Bitch. They staid the most part of the morning but never venturd to go above 20 yards from their canoe. The ribbands by which we had tied medals round their necks the first day we saw them were coverd with smoak; I suppose they lay much in the smoak to keep off the Musquetos. They are a very small people or at least this tribe consisted of very small people, in general about 5 feet 6 in hight and very slender; one we measurd 5 feet 2 and another 5 feet 9, but he was far taller than any of his fellows; I do not know by what deception we were to a man of opinion, when we saw them run on the sand about a mile from us, that they were taller and larger than we were. Their colour was nearest to that of chocolate, not that their skins were so dark but the smoak and dirt with which they were all casd over, which I suppose servd them instead of Cloths, made them of that colour. Their hair was strait in some and curld in others; they always wore it croppd close round their heads; it was of the same consistence with our hair, by no means wooly or curld like that of Negroes. Their eyes were in many lively and their teeth even and good; of them they had compleat setts, by no means wanting two of their fore teeth as Dampiers New Hollanders did. They were all of them clean limn'd, active and nimble. Cloaths they had none, not the least rag, those parts which nature willingly conceals being exposd to view compleatly uncoverd; yet when they stood still they would often or almost allways with their hand or something they held in it hide them in some measure at least, seemingly doing that as if by instinct. They Painted themselves with white and red, the first in lines and barrs on different Parts of their bodies, the other in large patches. Their ornaments were few: necklaces prettyly enough made of shells, bracelets wore round the upper part of their arms, consisting of strings lapd round with other strings as what we Call gymp in England, a string no thicker than a packthread tied round their bodies which was sometimes made of human hair, a peice of Bark tied over their forehead, and the preposterous bone in their noses which I have before mentiond were all that we observd. One had indeed one of his Ears bord, the hole being big enough to put a thumb through, but this was peculiar to that one man and him I never saw wear in it any ornament. Their language was totaly 
different from that of the Islanders; it sounded more like English in its degree of harshness tho it could not be calld harsh neither. They almost continualy made use of the Chircau, which we conceivd to be a term of Admiration as they still usd it when ever they saw any thing new; also Cherr, tut tut tut tut tut, which probably have the same signification. Their Canoe was not above 10 feet long and very narrow built, with an outrigger fitted much like those at the Islands only far inferior; they in shallow waters set her on with poles, in deep paddled her with paddles about 4 feet long; she just carried 4 people so that the 6 who visited us today were obligd to make 2 embarkations. Their Lances were much like those we had seen in Botany bay, only they were all of them single pointed, and some pointed with the stings of sting-rays and bearded with two or three beards of the same, which made them indeed a terrible weapon; the board or stick with which they flung them was also made in a neater manner.

\section{Resuming the Journey}

The Endeavour was now ready to resume it's journey but unfavourable winds plus the density of the unmapped coral reef made the gaining of open water perilous, as Banks describes below.

The ship was now finishd and tomorrow being the highest spring tide it was intended to haul her off, so we began to think how we should get out of this place, where so lately to get only in was our utmost ambition. We had observ'd in coming in innumerable shoals and sands all round us so we went upon a high hill to see what passage to the sea might be open. When we came there the Prospect was indeed melancholy: the sea every where full of innumerable shoals, some above and some under water, and no prospect of any streight passage out. To return as we came was impossible, the trade wind blew directly in our teeth; most dangerous then our navigation must be among unknown dangers. How soon might we again be reducd to the misfortune we had so lately escapd! Escapd indeed we had not till we were again in an open sea. $[\ldots]$

As the ship was now nearly ready for her departure Dr Solander and myself employd ourselves in winding up our Botanical Bottoms, examining what we wanted, and making up our complement of specimens of as many species as possible.[...] 
Our ship it is true was now repaird: Leaky she was from the strains she had got but the water she made was trifling. We were ready to sail with the first fair wind but where to go? - to windward was impossible, to leward was a Labyrinth of Shoals, so that how soon we might have the ship to repair again or lose her quite no one could tell. Encounter the dificulty however we must and since our Bargain was a bad one make the Best of it. At night the Yawl returnd with one turtle in her: it had blown so much since she had been out that she with dificulty took even that, for as all our turtle had been taken by chasing moderate weather was absolutely necessary.

Fine calm morn. Began early and warp'd the ship out, after which we saild right out till we came to the turtle reef where our turtlers took one turtle. Myself got some few shells but saw many Beautifull sea insects \&c. At night our people who fishd caught abundance of sharks. [...] Ship stood out for the opening we had seen in the reef and about 2 O'Clock passd it. It was about a mile wide. As soon as the ship was well without it we had no ground with100 fathm of Line so became in an instant quite easy, being once more in the main Ocean and consequently freed from all our fears of shoals \&c.

For the first time these three months we were this day out of sight of Land to our no small satisfaction: that very Ocean which had formerly been look'd upon with terror by (maybe) all of us was now the Assylum we had long wishd for and at last found. Satisfaction was clearly painted in every mans face: the day was fine and the trade wind brisk before which we steerd to the Northward; the well grown waves which followd the ship, sure sign of no land being in our neighbourhood, were contemplated with the greatest satisfaction, notwithstanding we plainly felt the effect of the blows they gave to our crazy ship, increasing her leaks considerably so that she made now 9 inches water every hour. This however was lookd upon as a light evil in comparison to those we had so lately made our escape from.

Fine weather and moderate trade. The Captn fearfull of going too far from the Land, least he should miss an opportunity of examining whether or not the passage which is layd down in some charts between New Holland and New Guinea realy existed or not, steerd the ship west right in for the land; about 12 O'Clock it was seen from the Mast head and about one the Reef laying without it in just the same manner as when we left it. He stood on however resolving to stand off at night after having taken a nearer view, but just at night fall found himself in a manner embayd in the reef so that it was a moot Point whether or not he could weather it on either tack; we stood however to the Northward and at dark it was concluded that she would 
go clear of every thing we could see. The night however was not the most agreable: all the dangers we had escapd were little in comparison of being thrown upon this reef if that should be our lot. A Reef such a one as I now speak of is a thing scarcely known in Europe or indeed any where but in these seas: it is a wall of Coral rock rising almost perpendicularly out of the unfathomable ocean, always overflown at high water commonly 7 or 8 feet, and generaly bare at low water; the large waves of the vast ocean meeting with so sudden a resistance make here a most terrible surf Breaking mountain high, especialy when as in our case the general trade wind blows directly upon it.

Sir Joseph Banks (1743-1870), The Endeavour Journal of Joseph Banks (1768-71)i

\section{Toucans and British MPs}

With others, Sydney Smith founded the Edinburgh Review in 1802 . He was a noted wit and in the following passage he compares a native of the forests of Cayenne, the toucan, to British politicians. (Cayenne is the capital of French Guiana located just above the equator in South America.)

"The toucan has an enormous bill, makes a noise like a puppy dog, and lays his eggs in a hollow tree. How astonishing are the freaks and fancies of nature! To what purpose, we say, is a bird placed in the woods of Cayenne, with a bill a yard long, making a noise like a puppy dog, and laying eggs in hollow trees? The toucans, to be sure, might retort, to what purpose were certain foolish prating Members of Parliament created?- pestering the House of Commons with their ignorance and folly, and impeding the business of the country? There is no end of such questions. So we will not enter into the metaphysics of the toucan."

Sydney Smith (1771-1845), "Waterton's Wanderings in South America," Edinburgh Review (1826)

\section{Insects: the Curse of Tropical Climates}

Sydney Smith on insects. 
Insects are the curse of tropical climates. The bête rouge lays the foundation of a tremendous ulcer. In a moment you are covered with ticks. Chigoes bury themselves in your flesh, and hatch a large colony of young chigoes in a few hours. They will not live together, but every chigoe sets up a separate ulcer, and has his own private portion of pus. Flies get entry into your mouth, into your eyes, into your nose; you eat flies, drink flies, and breathe flies. Lizards, cockroaches, and snakes, get into the bed; ants eat up the books; scorpions sting you on the foot. Every thing bites, stings, or bruises; every second of your existence you are wounded by some piece of animal life that nobody has ever seen before, except Swammerdam and Meriam. An insect with eleven legs is swimming in your teacup, a nondescript with nine wings is struggling in the small beer, or a caterpillar with several dozen eyes in his belly is hastening over the bread and butter! All nature is alive, and seems to be gathering all her entomological hosts to eat you up, as you are standing, out of your coat, waistcoat, and breeches. Such are the tropics. All this reconciles us to our dews, fogs, vapours, and drizzle - to our apothecaries rushing about with gargles and tinctures - to our old, British, constitutional coughs, sore throats, and swelled faces.

Sydney Smith (1771-1845), "Waterton's Wanderings in South America," Edinburgh Review (1826)

\section{Tameness of the Birds}

When Charles Darwin visited the Galapagos Archipelago he was profoundly struck by the tameness of the animals. Because he was able to observe animals at close quarters he described the variations in the shape and size of the beaks of related species of birds. This study eventually became key evidence in Darwin's theory of evolution, and the birds studied have become know as "Darwin's Finches". If species evolved to adapt to their particular habitat, then it was understandable that species in the Galapagos, which had no native human inhabitants, would not have acquired a fear of humans. The passage below, which describes and speculates on the tameness of the birds of the Galapagos, also conveys the awe and sense of wonder of the nineteenth-century naturalist confronted with seemingly magical scenes of tame animals. 
I will conclude my description of the natural history of these islands, by giving an account of the extreme tameness of the birds.

This disposition is common to all the terrestrial species; namely, to the mocking-thrushes, the finches, wrens, tyrant- flycatchers, the dove, and carrion-buzzard. All of them are often approached sufficiently near to be killed with a switch, and sometimes, as I myself tried, with a cap or hat. A gun is here almost superfluous; for with the muzzle I pushed a hawk off the branch of a tree. One day, whilst lying down, a mocking-thrush alighted on the edge of a pitcher, made of the shell of a tortoise, which I held in my hand, and began very quietly to sip the water; it allowed me to lift it from the ground whilst seated on the vessel: I often tried, and very nearly succeeded, in catching these birds by their legs. Formerly the birds appear to have been even tamer than at present. Cowley (in the year 1684) says that the "Turtledoves were so tame, that they would often alight on our hats and arms, so as that we could take them alive, they not fearing man, until such time as some of our company did fire at them, whereby they were rendered more shy." Dampier also, in the same year, says that a man in a morning's walk might kill six or seven dozen of these doves. At present, although certainly very tame, they do not alight on people's arms, nor do they suffer themselves to be killed in such large numbers. It is surprising that they have not become wilder; for these islands during the last hundred and fifty years have been frequently visited by bucaniers and whalers; and the sailors, wandering through the wood in search of tortoises, always take cruel delight in knocking down the little birds. These birds, although now still more persecuted, do not readily become wild. In Charles Island, which had then been colonized about six years, I saw a boy sitting by a well with a switch in his hand, with which he killed the doves and finches as they came to drink. He had already procured a little heap of them for his dinner, and he said that he had constantly been in the habit of waiting by this well for the same purpose. It would appear that the birds of this archipelago, not having as yet learnt that man is a more dangerous animal than the tortoise or the Amblyrhynchus, disregard him, in the same manner as in England shy birds, such as magpies, disregard the cows and horses grazing in our fields. 

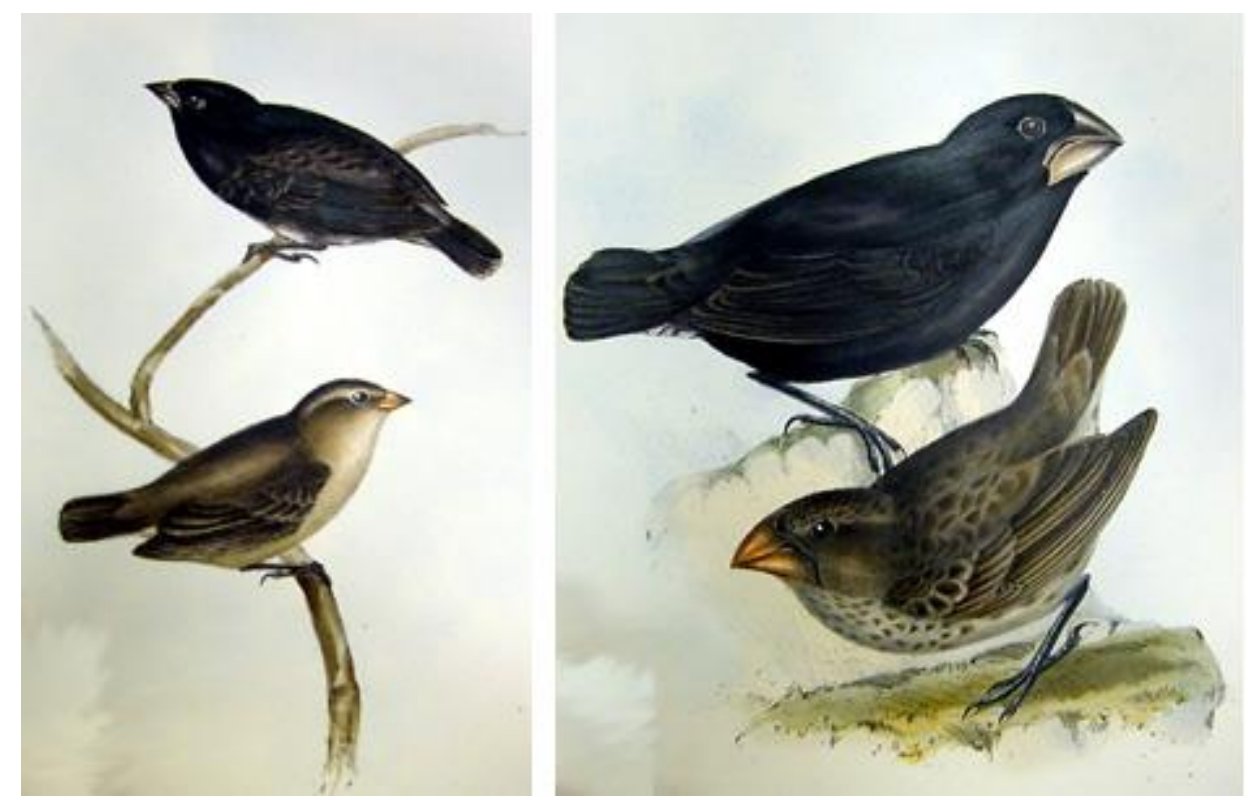

The Falkland Islands offer a second instance of birds with a similar disposition. The extraordinary tameness of the little Opetiorhynchus has been remarked by Pernety, Lesson, and other voyagers. It is not, however, peculiar to that bird: the Polyborus, snipe, upland and lowland goose, thrush, bunting, and even some true hawks, are all more or less tame. As the birds are so tame there, where foxes, hawks, and owls occur, we may infer that the absence of all rapacious animals at the Galapagos, is not the cause of their tameness here. The upland geese at the Falklands show, by the precaution they take in building on the islets, that they are aware of their danger from the foxes; but they are not by this rendered wild towards man. This tameness of the birds, especially of the waterfowl, is strongly contrasted with the habits of the same species in Tierra del Fuego, where for ages past they have been persecuted by the wild inhabitants. In the Falklands, the sportsman may sometimes kill more of the upland geese in one day than he can carry home; whereas in Tierra del Fuego it is nearly as difficult to kill one, as it is in England to shoot the common wild goose.

In the time of Pernety (1763), all the birds there appear to have been much tamer than at present; he states that the Opetiorhynchus would almost perch on his finger; and that with a wand he killed ten in half an hour. At that period the birds must have been about as tame as they now are at the Galapagos. They appear to have learnt caution more slowly at these latter islands than at the Falklands, where they have had proportionate means of experience; for besides frequent visits from vessels, those islands have been at intervals colonized during the entire period. Even formerly, when all the birds were so tame, it was impossible by Pernety's 
account to kill the black-necked swan -- a bird of passage, which probably brought with it the wisdom learnt in foreign countries.

I may add that, according to Du Bois, all the birds at Bourbon in 1571-72, with the exception of the flamingoes and geese, were so extremely tame, that they could be caught by the hand, or killed in any number with a stick. Again, at Tristan d'Acunha in the Atlantic, Carmichael states that the only two land-birds, a thrush and a bunting, were "so tame as to suffer themselves to be caught with a hand-net." From these several facts we may, I think, conclude, first, that the wildness of birds with regard to man, is a particular instinct directed against him, and not dependent upon any general degree of caution arising from other sources of danger; secondly, that it is not acquired by individual birds in a short time, even when much persecuted; but that in the course of successive generations it becomes hereditary. With domesticated animals we are accustomed to see new mental habits or instincts acquired or rendered hereditary; but with animals in a state of nature, it must always be most difficult to discover instances of acquired hereditary knowledge. In regard to the wildness of birds towards man, there is no way of accounting for it, except as an inherited habit: comparatively few young birds, in any one year, have been injured by man in England, yet almost all, even nestlings, are afraid of him; many individuals, on the other hand, both at the Galapagos and at the Falklands, have been pursued and injured by man, yet have not learned a salutary dread of him. We may infer from these facts, what havoc the introduction of any new beast of prey must cause in a country, before the instincts of the indigenous inhabitants have become adapted to the stranger's craft or power.

Charles Darwin (1809-82), Journal of Researches into the Geology and Natural History of the various countries visited by H.M.S. Beagle (1839) 


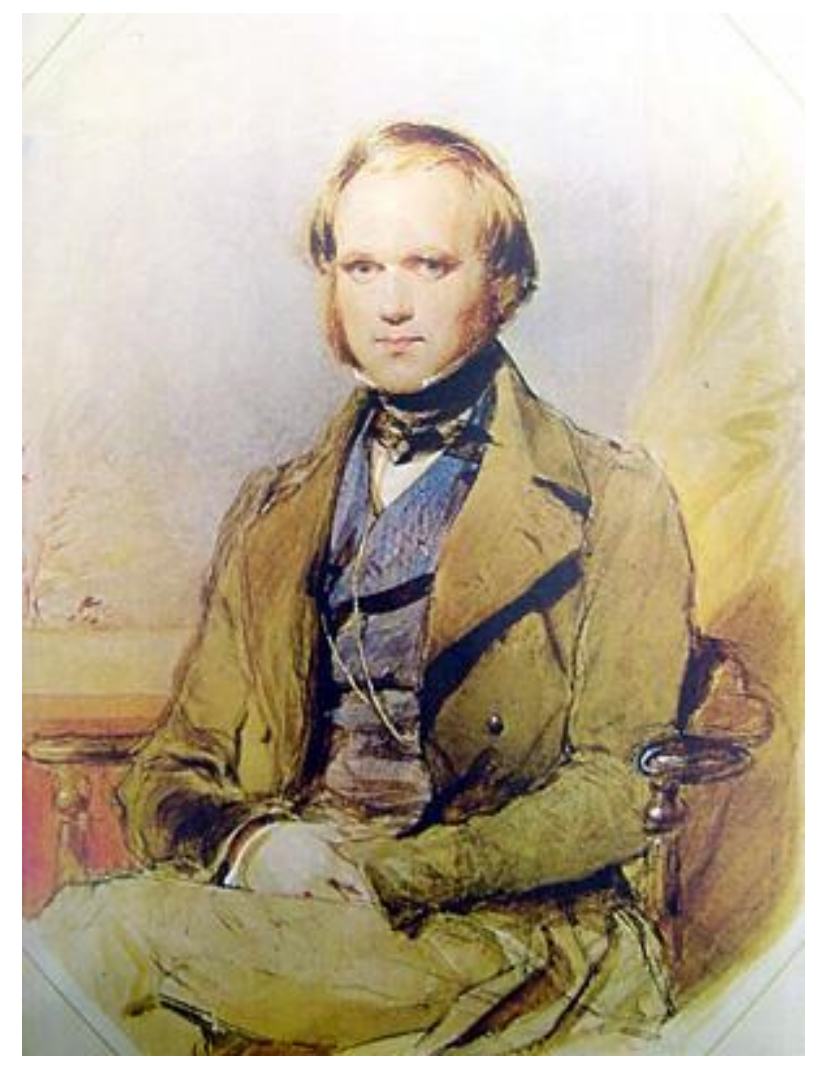

The young Darwin

\section{A Mexican Panorama}

William Hickling Prescott (1796-1859) was born in Massachuesetts an educated at Harvard. He was an expert in Spanish literature and history and wrote the history of Ferdinand and Isabella as well as histories of the Spanish conquests of Mexico and Peru.

They had not advanced far, when, turning an angle of the sierra, they sudenly came on a view which more than compensated the toils fo the preceding day. It was that of the valley of Mexico, or Tenochtitlan, as more commonly called by the natives; which, with its pictureque assemblage of water, woodland, and cultivated plains, its shining cities and shadowy hills, was spread out like some gay and gorgeous panorma before them. In the highly rarefied atmosphere of these upper regions, even remote objects have a brilliancy of colouring and a distinctness of outline which seem to ahnnihilate distance. Stretching far away at their feet were seen noble forests of oak, sycamore, and cedar, and beyond, yellow fields of maize and the towering maguey, intermingled with orchards and blooming gardens; for flowers, in such demand for their religious festivals, were even more abundant in this populous valley than in 
outer parts of Ahahuac. In the centre of the great basin were beheld the lakes, occupying then a much larger portion of its surface than at present; their borders thickly studded with towns and hamlets, and in the midst-like some Indian empress with her coronal of pearls - the fairist city of Mexico, with her white towers and pyramidal temples, reposing, as were, on the bosom of the waters - the far-famed 'Venice of the Aztecs'. High over all rose the royal hill of Chapoltepec, the residence fo the Mexican monarchs, crowned withe the same grove of gigantic cypresses which at this day fling their broad shadows over the land. In the distance beyond the blue waters of the lake, and nearly screened by intervening foliage, was seen a shining speck, the rival captital of Tezcuco, and, still further on, the dark belt of the porphyry, girdiling the valley around like a rich setting which Nature had devised for the fairest of her jewels.

Such was the beautiful vision which broke on the eyes of the Conquerors. And even now, when so sad a change has come over the scene; when the stately forests have been laid low, and the soil, unsheltered from the fierce radiance of a tropical sun, is in many places abandoned to sterility; when the waters have retired, leaving a broad and ghastly margin white with the incrustatin of salts, while the cities and hamlets on their borders have mouldered into ruins; - - even now that desolation broods over the landscape, so indestructible are the lines of beauty which Nature has traced on its features, that no traveller, however cold, can gaze on them with any other emotions than those of astonishment and rapture.

What then, must have been the emotions of the Spaniards, when, after working their toilsome way into the upper air, the cloudy tabernacle parted beofre their eyes, and they beheld these fair scenes in all their pristine magninficence and beauty! It was like the spectacle which greeted the eyes of Moses from the summit of Pisgah; and, in the warm glow of their feeling, they cried out, 'It is the promised land!'

William H. Prescott (1796-1895) History of the Conquest of Mexico (1843)

\section{Birds of Paradise}

Alfred Russel Wallace (1823-1913) was an English naturalist with a broad interest in anthropology, sociology and geography. He was also one of the first to explore theories of biological evolution. He was a friend of Henry Bates and accompanied him to South America 
where he explored the middle Amazon and the Rio Negro regions. From 1854 to 1862 he travelled to South East Asia and as a result wrote what is now regarded as his masterpiece and the best nineteenth-century travel narrative of Indonesia. In 1958 while in the Moluccas his studies led him to the intution that natural selection was the process underlying speciation. He wrote to his colleague Charles Darwin, who was precipated into releasing his own similar ideas along with Wallace's at the now famous Linnean Society meeting on 1st of July 1858.

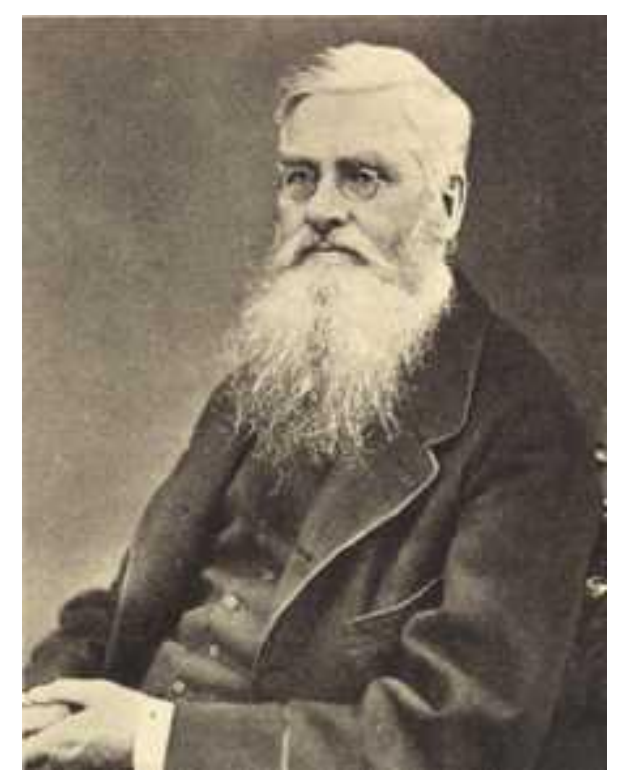

In this selection from Chapter 31 of the second volume of The Malay Archipelago, Wallace recounts his visit to the Aru Islands (during March to May of 1857) where he hopes, among other things, to capture some Birds of Paradise. Upon examing the birds, Wallace's emotional reactions typically lead him into broader philosphical considerations.

The first two or three days of our stay here were very wet, and I obtained but few insects or birds, but at length, when I was beginning to despair, my boy Baderoon returned one day with a specimen which repaid me for months of delay and expectation. It was a small bird a little less than a thrush. The greater part of its plumage was of an intense cinnabar red, with a gloss as of spun glass. On the head the feathers became short and velvety, and shaded into rich orange. Beneath, from the breast downwards, was pure white, with the softness and gloss of silk, and across the breast a band of deep metallic green separated this colour from the red of the throat. Above each eye was a round spot of the same metallic green; the bill was yellow, and the feet and legs were of a fine cobalt blue, strikingly contrasting with all the other parts of the body. Merely in arrangement of colours and texture of plumage this little bird was a gem of the first order, yet there comprised only half its strange beauty. Springing 
from each side of the breast, and ordinarily lying concealed under the wings, were little tufts of greyish feathers about two inches long, and each terminated by a broad band of intense emerald green. These plumes can be raised at the will of the bird, and spread out into a pair of elegant fans when the wings are elevated. But this is not the only ornament. The two middle feathers of the tail are in the form of slender wires about five inches long, and which diverge in a beautiful double curve. About half an inch of the end of this wire is webbed on the outer side only, and coloured of a fine metallic green, and being curled spirally inwards form a pair of elegant glittering buttons, hanging five inches below the body, and the same distance apart. These two ornaments, the breast fans and the spiral tipped tail wires, are altogether unique, not occurring on any other species of the eight thousand different birds that are known to exist upon the earth; and, combined with the most exquisite beauty of plumage, render this one of the most perfectly lovely of the many lovely productions of nature. My transports of admiration and delight quite amused my Aru hosts, who saw nothing more in the "Burong raja" than we do in the robin or the goldfinch.

Thus one of my objects in coming to the far East was accomplished. I had obtained a specimen of the King Bird of Paradise (Paradisea regia), which had been described by Linnaeus from skins preserved in a mutilated state by the natives. I knew how few Europeans had ever beheld the perfect little organism I now gazed upon, and how very imperfectly it was still known in Europe. The emotions excited in the minds of a naturalist, who has long desired to see the actual thing which he has hitherto known only by description, drawing, or badly-preserved external covering - especially when that thing is of surpassing rarity and beauty, require the poetic faculty fully to express them. The remote island in which I found myself situated, in an almost unvisited sea, far from the tracks of merchant fleets and navies; the wild luxuriant tropical forest, which stretched far away on every side; the rude uncultured savages who gathered round me,- - all had their influence in determining the emotions with which I gazed upon this "thing of beauty." I thought of the long ages of the past, during which the successive generations of this little creature had run their course-year by year being born, and living and dying amid these dark and gloomy woods, with no intelligent eye to gaze upon their loveliness; to all appearance such a wanton waste of beauty. Such ideas excite a feeling of melancholy. It seems sad, that on the one hand such exquisite creatures should live out their lives and exhibit their charms only in these wild inhospitable regions, doomed for ages yet to come to hopeless barbarism; while on the other hand, should civilized man ever reach these distant lands, and bring moral, intellectual, and physical light into the 
recesses of these virgin forests, we may be sure that he will so disturb the nicely-balanced relations of organic and inorganic nature as to cause the disappearance, and finally the extinction, of these very beings whose wonderful structure and beauty he alone is fitted to appreciate and enjoy. This consideration must surely tell us that all living things were not made for man. Many of them have no relation to him. The cycle of their existence has gone on independently of his, and is disturbed or broken by every advance in man's intellectual development; and their happiness and enjoyment, their loves and hates, their struggles for existence, their vigorous life and early death, would seem to be immediately related to their own well-being and perpetuation alone, limited only by the equal well-being and perpetuation of the numberless other organisms with which each is more or less intimately connected. $\mathrm{i}$

Alfred Russell Wallace (1823-1913) The Malay Archipelago (1869)

\section{The Equatorial Seasonal Pattern}

Henry Walter Bates (1825-1892) was a keen naturalist who identified more than 8,000 species. With another eminent naturalist, Alfred Russel Wallace, he undertook a trip to the dense tropical rainforests of Pará in northern Brazil in 1848. From 1851 to 1859 he travelled on the Amazon and his observations were published as The Naturalist on the Amazons. In the following extract from this work, Bates discusses the characteristic diurnal and seasonal pattern of equatorial regions of South America.

The two hours before breakfast were devoted to ornithology. At that early period of the day the sky was invariably cloudless (the thermometer marking $72^{\circ}$ or $73^{\circ}$ Fahr.); the heavy dew of the previous night's rain, which lay on the moist foliage, becoming quickly dissipated by the glowing sun, which, rising straight out of the east, mounted rapidly towards the zenith. All nature was fresh, new leaf and flower-buds expanding rapidly. Some mornings a single tree would appear amidst what was the preceding evening a uniform green mass of forest- $\mathrm{a}$ dome of blossom suddenly created as if by magic. The birds were all active; from the wildfruit trees, nor far off, we often heard the shrill yelping of the Toucans (Rhamphastos vitellinus). Small flocks of parrots flew over on most mornings, at a great height, appearing in distinct relief against the blue sky, always two by two, chattering to each other, the pairs being separated by regular intervals; their bright colours, however, were not apparent at that 
height. After breakfast we devoted the hours from 10 a.m. to 2 or 3 p.m. to entomology; the best time for insects in the forest being a little before the greatest heat of the day. We did not find them at all numerous, although of great variety as to species. [...]

The heat increased rapidly towards two o'clock ( $92^{\circ}$ and $93^{\circ}$ Fahr.), by which time every voice of bird and mammal was hushed; only in the trees was heard at intervals the harsh whirr of a cicada. The leaves, which were so moist and fresh in early morning, now became lax and drooping; the flowers shed their petals. Our neighbours, the Indian and Mulatto inhabitants of the open palm-thatched huts, as we returned home fatigued with our ramble, were either asleep in their hammocks or seated on mats in the shade, too languid even to talk. On most days in June and July a heavy shower would fall some time in the afternoon, producing a most welcome coolness. The approach of the rain-clouds was after a uniform fashion, very interesting to observe. First, the cool sea-breeze, which commenced to blow about 10 o'clock, and which had increased in force with the increasing power of the sun, would flag and finally die away. The heat and electric tension of the atmosphere would then become almost insupportable. Languour and uneasiness would seize on every one; even the denizens of the forest betraying it by their motions. White clouds would appear in the east and gather into cumuli, with an increasing blackness along their lower portions. The whole eastern horizon would become almost suddenly black, and this would spread upwards, the sun at length becoming obscured. Then the rush of a mighty wind is heard through the forest, swaying the tree-tops; a vivid flash of lightning bursts forth, then a crash of thunder, and down streams the deluging rain. Such storms soon cease, leaving bluish-black motionless clouds in the sky until night. Meantime all nature is refreshed; but heaps of flower-petals and fallen leaves are seen under the trees. Towards evening life revives again, and the ringing uproar is resumed from bush and tree. The following morning the sun again rises in a cloudless sky, and so the cycle is completed; spring, summer, and autumn, as it were, in one tropical day.

In Europe, a woodland scene has its spring, its summer, its autumnal, and its winter aspects. In the equatorial forests the aspect is the same or nearly so every day in the year: budding, flowering, and leaf-shedding are always going on in one species or other. The activity of birds and insects proceeds without interruption, each species having its own separate times; the colonies of wasps, for instance, do not die off annually, leaving only the queens, as in cold climates; but the seccession of generations and colonies goes on incessantly. It is never 
either spring, summer, or autumn, but each day is a combination of all three. With the day and night always of equal length, the atmospheric disturbances of each day neutralising themselves before each succeeding morn; with the sun in its course proceeding mid-way across the sky, and the daily temperature the same within two or three degrees throughout the year-how grand in its perfect equilibrium and simplicity is the march of Nature under the equator!

Henry Walter Bates (1825-92), The Naturalist on the Amazons (1863)

\section{Crossing the Equator}

Samuel Langhorne Clemens (1835-1910) achieved fame and literary success with his novels The Adventures of Tom Sawyer and The Adventures of Hucklebury Finn written under the pseudonym of Mark Twain. His travel wrtitings, like Life on the Mississippi and Innocents Abroad, combine curiosity with irrascible humour and acute insight into nature and culture, both at home and abroad. Below, in an extract from Following the Equator, Twain's focus is on the human anticipation of reaching the imaginary line.

Sailed from Honolulu.-From diary:

Sept. 2. Flocks of flying fish—slim, shapely, graceful, and intensely white. With the sun on them they look like a flight of silver fruit-knives. They are able to fly a hundred yards.

Sept. 3. In 9 deg. 50' north latitude, at breakfast. Approaching the equator on a long slant. Those of us who have never seen the equator are a good deal excited. I think I would rather see it than any other thing in the world. We entered the "doldrums" last nightvariable winds, bursts of rain, intervals of calm, with chopping seas and a wobbly and drunken motion to the ship - a condition of things findable in other regions sometimes, but present in the doldrums always. The globe-girdling belt called the doldrums is 20 degrees wide, and the thread called the equator lies along the middle of it.

Sept. 4. Total eclipse of the moon last night. At 1.30 it began to go off. At total—or about that - it was like a rich rosy cloud with a tumbled surface framed in the circle and projecting 
from it — a bulge of strawberry-ice, so to speak. At half-eclipse the moon was like a gilded acorn in its cup.

Sept. 5. Closing in on the equator this noon. A sailor explained to a young girl that the ship's speed is poor because we are climbing up the bulge toward the center of the globe; but that when we should once get over, at the equator, and start down-hill, we should fly. When she asked him the other day what the fore-yard was, he said it was the front yard, the open area in the front end of the ship. That man has a good deal of learning stored up, and the girl is likely to get it all.

Afternoon. Crossed the equator. In the distance it looked like a blue ribbon stretched across the ocean. Several passengers kodak'd it. We had no fool ceremonies, no fantastics, no horse play. All that sort of thing has gone out. In old times a sailor, dressed as Neptune, used to come in over the bows, with his suite, and lather up and shave everybodywho was crossing the equator for the first time, and then cleanse these unfortunates by swinging them from the yard-arm and ducking them three times in the sea. This was considered funny. Nobody knows why. No, that is not true. We do know why. Such a thing could never be funny on land; no part of the old-time grotesque performances gotten up on shipboard to celebrate the passage of the line would ever be funny on shore - they would seem dreary and less to shore people. But the shore people would change their minds about it at sea, on a long voyage. On such a voyage,with its eternal monotonies, people's intellects deteriorate; the ownersof the intellects soon reach a point where they almost seem to prefer childish things to things of a maturer degree. One is often surprised at the juvenilities which grown people indulge in at sea, and the interest they take in them, and the consuming enjoyment they get out of them.

This is on long voyages only. The mind gradually becomes inert, dull, blunted; it loses its accustomed interest in intellectual things; nothing but horse-play can rouse it, nothing but wild and foolish grotesqueries can entertain it. On short voyages it makes no such exposure of itself; it hasn't time to slump down to this sorrowful level.

Mark Twain (1835-1910), Following the Equator: A Journey Around the World (1897)

\section{Tropical Conservatories and Hothouses in the Nineteenth Century}


In Chapter 9 of Landscape and Memory (London, Fontana Press: 1996) Simon Schama discusses how advances in building methods and materials technology during the nineteenth century allowed Europeans to create conservatories capable of supporting tropical flora and fauna, thereby satisfying a long standing scientific and popular fascination with wild arcadia.

The bolder zoo-designers, in the middle of the nineteenth century, were not content merely with shipping and showing wild animals housed in various types of European domestic architecture. Their zoological imperialism aimed at reproducing tropical micro-environments, complete with running water, artificial rock, and, above all, the vegetation that would give the displays an appearance of authenticity. And the most ambitious of all was Carl Hagenbeck, who at his own zoo in Stellingen, near Hamburg, adapted the pastoral ha-ha to create trenched enclosures and paddocks for the wild animals he had brought from the tropics. The effect was meant to be identical to Bridgeman's eighteenth-century country-house park, with an illusion of continuity established between the landowner (or in this case the European zoo spectator) and his herds (in this case wildebeest and leopards rather than sheep and cattle). It was of a piece with this design of actually bringing whole savage landscapes into the world of bourgeois-imperial Germany that Hagenbeck also mounted displays of human savages, from Inuits to Hottentots, along with his animal paddocks.

The pseudo-naturalization of the zoos could only have happened with an ample supply of tropical plants. And what went for the fauna of the wild arcadia certainly went for the flora. The difference between the attempts of the Renaissance botanists to encompass the world in a garden and imperial tropical gardening of the nineteenth century was simply the industrial marriage of glass panes and iron ribs. Once these had been successfully fitted through the ridge-and-furrow engineering devised by John Claudius Loudun, the limits imposed by masonry or wooden-framed windows on the traditional conservatory disappeared in a great blaze of light. When forced hot-water heating was added, whole forests of exotic vegetation could luxuriate beneath the glass. And since iron columns could bear the load of the glass on relatively slender piers, the material could itself be cast or worked to disguise its own solidity. Some columns even sprouted tendrils and garlands; others acted as trellises for creepers and vines. In1842, a French designer of glasshouses, suggesting how far this illusion of a technologically produced Eden could go, urged gardeners to imitate "the rich disorder of the primeval forest. The miraculous space within would no longer simply be an arrangement of tropical plants but an entire landscape of wood, water, and rock: the original 
arcadia with its venom drained off. In the midst of carefully chosen lighting a stream must meander, populated with tropical fish, murmuring its way between rocks, then spreading out placid and still into a side stream bordered with sand and pebbles.

Initially, such imperial arcadia were available only to the rich and aristocratic. It cost the duke of Devonshire thirty thousand pounds for this gardener Joseph Paxton to build the Great Stove, nearly three hundred feet long and sixty-seven feet high. This colossus of palm houses used eight coal-fired furnaces to send hot water through seven miles of pipes, all carefully concealed beneath a stone floor lest the illusion of paradise-come-to-Derbyshire be spoiled for the duke. Sub-tropicals like hibiscus and bougainvillea threw bombs of brilliant color within the dense greenery of palms and dracaena. Brilliant birds flew about in the steamy radiance. In the bleakest moment of the year, December 1843, Queen Victoria came to see both the Great Stove and the special glasshouse that Paxton had built solely to house the duke's gigantic water lilies, obediently named the Victoria regia. Twelve thousand gas lamps lit the crystal; a fountain, driven by a concealed steam pump (the ultimate legacy of the great Salomon Caus), sent a spray fifty feet high, and the duke of Wellington pronounced the whole thing the most magnificent coup d'oeil he had ever seen. $\mathrm{i}$

The Chatsworth conservatory was open to the public gratis. But even when railway travel shortened distances, access was still necessarily limited. And some of the most spectacular collections of palms and tropical plants, birds and fish were private reserves of the European monarchies, like the palm conservatory the king of Prussia, Frederick William III, built on the Pfaueninsel at the southern end of the Wannsee in 1830. Predictably, the most private of all was also the most fantastic: the realm of grottoes, jungles, and orchids built for Ludwig II of Bavaria, set (incongruously) in a painted setting of the Himalayas and accessible only through the king's private apartments. There, beneath the peaks and palms, the king would sit dreaming on a rock, drifting his hand in the warm water while a servant dressed as Lohengrin (or possibly the Swan) would periodically cruise past.

Simon Shama. Landscape and Memory (1996)

\section{The Congo}


Famed modernist novelist Joseph Conrad (1857-1924) made a trip to the Congo which became the basis for his novella Heart of Darkness (1902). In the extract below he conveys what he felt was a primeval force in the landscape and its influence on the human psyche.

Going up that river was like travelling back to the earliest beginnings of the world, when vegetation rioted on the earth and the big trees were kings. An empty stream, a great silence, an inpenetrable forest. The air was warm, thick, heavy, sluggish. There was no joy in the briliance of sunshine. The long stretches of the waterway ran on, deserted, into the gloom of overshadowed distances. On silvery sandbanks hippos and alligators sunned themselves side by side. The broadening waters flowed through a mob of wooded islands; you lost your way on that river as you would in a desert, and butted all day long aginast shoals, trying to find the channel, till you thought yourself bewitched and cut off for ever from everything you had known once - somewhere - far away — in another existence perhaps. There were moments when one's past came back to one, as it will sometimes when you have not a moment to spare to yourself; but it came in the shape of an unrestful and noisy dream, remembered with wonder amonst the overwhhelming realities of this strange world of plants, and water, and silence. And this stillness of life did not in the least resemble a peace. It was the stillness of an implacable force brooding over an inscrutable intention. It looked at you with a vengeful aspect.

Joseph Conrad (1857-1924) Heart of Darkness (1902)

\section{A Surrealist on the Great Barrier Reef}

In his novel Mad Love, Andre Breton associates crystalline structures with "convulsive beauty"and gives the corals of the Great Barrier Reef as an example of such crystals:

This dominion of the senses which stretches over all the domains of my mind, residing in a sheaf of light rays within reach, is, I think, fully shared from time to time only by those absolute bouquets formed in the depths by the alcyonaria, the madrepores. Here the inanimate is so close to the animate that the imagination is free to play infinitely with these apparently mineral forms, reproducing their procedure of recognizing a nest, a cluster drawn from a petrifying fountain. After some castle towers three-quarters ruined, rock crystal towers with their summit in the sky and their feet in fog, from one of whose blue and gilt windows there 
streams the hair of Venus, after these towers, as I was saying, a whole garden appears: the giant reseda, the hawthorn whose stem, whose leaves, whose thorns even, are of the very substance of flowers, the fans of frost. If the very place where the "figure" - in the Hegelian sense of the material mechanism of individuality, beyond magnetism - attains its reality is above all the crystal, then in my view the place where it ideally loses this omnipotent reality is the coral, reintegrated as it should be in life, into the dazzling sparkle of the sea. Life, in its constant formation and destruction, seems to me never better framed for the human eye than between the hedges of blue titmouses of aragonite and the treasure bridge of Australia's Great Barrier Reef.

André Breton (1896-1966), Mad Love. Trans. Mary Ann Caws. Lincoln: University of Nebraska Press, 1987. Originally pub as L'Amour fou (1937)

\section{The Stellar Heaven of the Equator}

Isak Dinesen (1885-1962) was a Danish writer who went to East Africa in 1914 and, with her husband, Baron von Blixen, lived on a coffee plantation. After a divorce in 1921, she ran the plantation herself for a decade. The following is an extract from her autobiography, dealing with her life during the years she spent in Kenya.

On the evening of the nineteenth of December, I walked out of my house before going to bed, to see if there was any rain coming. Many farmers in the highlands were, I believe, doing the same thing at that hour. Sometimes, in a lucky year, we would get a few heavy showers just round Christmas, and it was a great thing for the young coffee, which has set on the trees after the flowering in the short rains of October. This night there was no sign of rain. The sky was serene and silently triumphant, resplendent with stars.

The Stellar Heaven of the Equator is richer than that of the North, and you see it more because you are out more at night. In Northern Europe, winter nights are too cold to allow one much pleasure in the contemplation of the stars, and in summer one hardly distinguishes them within the clear night sky, that is as pale as a dog-violet.

The tropical night has the companionability of a Roman Catholic Cathedral compared to the Protestant Churches of the North, which let you in on business only. Here in the great room 
everybody comes and goes, this is the place where things are going on. To Arabia and Africa, where the sun of the midday kills you, night is the time for travelling and enterprise. The stars have been named here, they have been guides to human beings for many centuries, drawing them in long lines across the desert-sands and the Sea, one towards the East, and another to the West, or the North and South. Cars run well at night, and it is pleasant to motor under the stars, you get into the habit of fixing visits to friends up-country by the time of the next full moon.You start safaris by the new moon, to have the benefit of the whole row of moonlight nights. It is then strange, when back on a visit to Europe, to find your friends of the towns living out of touch with the moves of the moon and almost in ignorance of them. [...]

The farmer slowly turns his eyes all round the Horizon. First to the East, for from the West, if it comes, comes the rain, and there stands clear Spica in the Virgin. Then South, to greet the Southern Cross, doorkeeper of the great world, faithful to travellers and beloved by them, and higher up, under the luminous streak of the Milky Way, Alpha and Beta in the Centaur. To the South West sparkles Sirius, great in heaven, and the thoughtful Canopus, and to the West above the faint outline of the Ngong Hills, now nearly unbroken, the radiant diamond ornament, Rigel, Betelgeuze and Bellatrix. He turns to the North last, for to the North we go back in the end, and there he runs upon the Great Bear himself, only he is now calmly standing on his head on account of the heavenly perspective, and that has all the air of a bearish joke, that cheers the heartg of the Nordic emigrant.

Isak Dinesen (1885-1962), Out of Africa (1937)

\section{Crocodiles in Verse}

Ogden Nash give a humorous correction of the common cunfusion between alligators and crocodiles in his poem "The Purist".

I give you now Professor Twist,

A conscientious scientist.

Trustees exclaimed, 'He never bungles?'

And sent him off to distant jungles.

Camped on a tropic riverside,

One day he missed his living bride. 
She had, the guide informed him later,

Been eaten by an alligator.

Professor Twist could not but smile.

'You mean,' he said, 'a crocodile.'

Ogden Nash (1902-1971), Verses from 1929 On (1959)

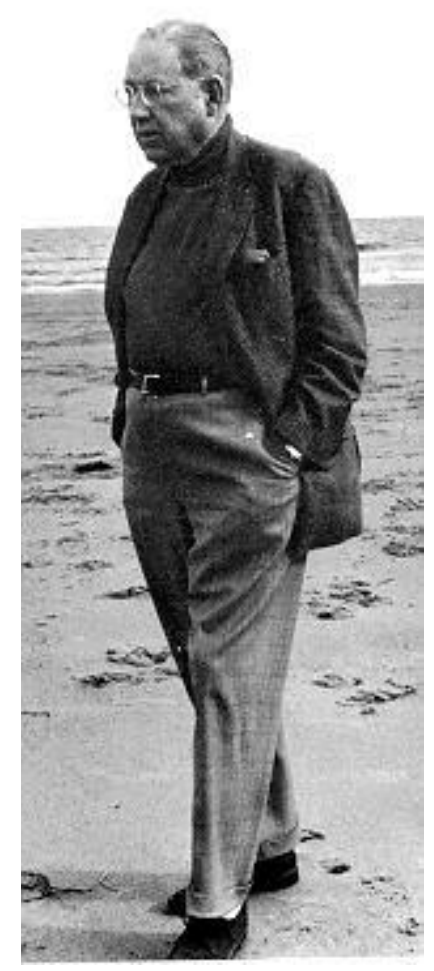

\section{The Northern Australian 'Wet'}

Xavier Herbert's novel Capricornia, named after "that northern part of the Continent of Australia" is rich with descriptions of tropical environments. One of its main characters, Norman (or Nawnim, meaning no name) is a part aboriginal whose search for identity involves geographical as well as psychological journeying. In one of his travels he is trapped by the monsoonal weather which is a feature of northern Australian summers:

"Now I wanter get back home, “ said Norman.

"Carn do it, "said Bootpolish. "Big-fella Wet come properly."

"Eh—can't I get round somewhere?"

"Too muchee water." 
"But I gotter get home," cried Norman.

“Carn do it,' said Bootpolish. 'dis one wet-time. Can’t go nowhere. You askim Muttonhead. Him ol' man boss belonga me-fella. Him savvy."

Norman's old friend Muttonhead grinned at him and told him that he could not hope to reach home for four or five more moons.

"But—but I gotter get back South, ' gasped Norman. Or I'll lose me job."

Muttonhead picked up the rifle and eyeing it said, "more better you stop long me-fella."

"But I can't——“

More better stop. You harcarse. Plenty harcase stop longa bush longa blackfella.”

"I-I mean I gotter-

"Proper good country dis one. Plenty kangaroo, plenty buffalo, plenty bandicoot, plenty yam, plenty goose, plenty duck, plenty lubra, plenty corroborre, plenty fun, plenty ebrytings.

Number-one good country. More better you sit down all-same blackfella—eh Norman? Dat lo-ng lo-ng time you gotter wait-You gottim plenty baccy?"

The luxuriance, the biodiversity, and, at the same time, the polarities of the tropics are vividly pictured in Xavier Herbert's Capricornia:

Jasmine had said that [Oscar] worhipped property. It was true. But he did not value Red Ochre simply as a grazing-lease. At times it was to him six hundred sqare miles where grazing grew and brolgas danced in the painted sunset and emus ran to the silver dawnsquare miles of jungle where cool deep billabongs made watering for stock and nests for shouting nuttagul geese - of grassy valleys and stony hills, useless for grazing, but good to think about as haunts of great goannas and rock-pythons - of swamps where cattle bogged and died, but wild hog and buffalo wallowed in happiness - of virgin forests where poison weed lay in wait for stock, but where possums and kangaroos and multitudes of gorgeous birds dwelt as from time immemorial. At times he loved Red Ochre.

At times he loved it best in the Wet Season-when the creeks were running and the swamps were full—when the multi-coloured schisty rocks split golden waterfalls — when the billabongs were brimming and the water-lilies bloomming and the nuttaguls shouting loudest - when bull-grass towered ten feet high, clothing hills and choking gullies — when every tree was flowering and most were draped with crimson mistletoe and droning with humming-birds and native bees - when cattle wandered a land of plenty, fat and sleek, till the buffalo-flies and marsh-flies came and drove them mad, so that they ran and ran to leanness, 
often to their death — when mosquitoes and a hundred other breeds of maddening insects were there to test a man's endurance-when from hour to hour luke-warm showers drenched the steaming earth, till one was sodden to the bone, and mildewed to the marrow and moved to pray, as Oscar always was when he had had enough of it, for that which formerly he had cursed — the Dry! the good old Dry—when the grasses yellowed, browned, dried to tinder, burst into spontaneous flame- - when harsh winds rioted with choking dust and the billabongs became mere muddy holes where cattle pawed for water-when gaunt drought loafed about a desert and exhausted cattle staggered searching dust for food and drink, till they fell down and died and became neat piles of bones for the wind to whistle through and the gaunt-ribbed dingo to mourn - then one prayed for the Wet again, or if one's heart were small, packed up and left this Capricornia that fools down south called the Land of Opportunity, and went back and said that noting was done by halves up there except the works of puny man.

Xavier Herbert (1901-84), Capricornia (1938)

\section{Palm-Wine Drinking}

Nigerian writer, Amos Tutuola (1920-1997), drew on his native Yoruba mythology in his novel The Palm-Wine Drinkard (1952) written in a colloquial 'pidgin' English. The myth tells how a life-long devotee of palm wine journeys into the land of the dead to bring back his favourite tapster who has died.

I was a palm-wine drinkard since I was a boy of ten years of age. I had no other work more than to drink palm-wine in my life. In those days we did not know other money, except COWRIES, so that everything was very cheap, and my father was the richest man in our town.

My father got eight children and I was the eldest among them, all of the rest were hard workers, but I myself was an expert palm-wine drinkard. I was drinking palm-wine from morning till night and from night till morning. By that time I could not drink ordinary water at all except palm-wine.

But when my father noticed that I could not do any work more than to drink, he engaged an expert palm-wine tapster for me; he had no other work more than to tap palm-wine every day. 
So my father gave me a palm-tree farm which was nine miles square and it contained 560,000 palm-trees, and this palm-wine tapster was tapping one hundred and fifty kegs of palm-wine every morning, but before 2 o'clock p.m., I would have drunk all of it; after that he would go and tap another $75 \mathrm{kegs}$ in the evening which I would be drinking till morning. So my friends were uncountable by that time and they were drinking palm-wine with me from morning till a late hour in the night. But when my palm-wine tapster completed the period of 15 years that he was tapping the palm-wine for me, then my father died suddenly, and when it was the 6th month after my father had died, the tapster went to the palm-tree farm on a Sunday evening to tap palm-wine for me. When he reached the farm, he climbed one of the tallest palm-trees in the farm to tap palm-wine but as he was tapping on, he fell down unexpectedly and died at the foot of the palm-tree as a result of injuries. As I was waiting for him to bring the palmwine, when I saw that he did not return in time, because he was not keeping me long like that before, then I called two of my friends to accompany me to the farm. When we reached the farm, we began to look at every palm-tree, after a while we found him under the palm-tree, where he fell down and died.

But what I did first when we saw him dead there, was that I climbed another palm-tree which was near the spot, after that I tapped palm-wine and drank it to my satrisfactoin before I came back to the spot. Then both my friends who accompanied me to the farm and I dug a pit under the palm-tree that he fell down as a grave and buried him there, after that we came back to the town.

When it was early in the morning of the next day, I had no palm-wine to drink at all, and throughout that day I felt not so happy as before; I was serioulsy sat down in my parlour, but when it was the third day that I had no palm-wine at all, all my firends did not come to my house again, they left me there alone, because there was no palm-wine for them to drink.

But when I completed a week in my house without palm-wine, then I went out and, I saw one of them in the town, so I saluted him, he answered but did not approach me at all, he hastily went away.

Then I started to find out another expert palm-wine tapster, but I could not get me one who could tap the palm-wine to my requirement. When there was no palm-wine for me to drink I sarted to drink ordinary water which I was unable to taste before, but I did not satisfy with it as palm-wine. 
etropic 1.1 (2002): Torre: Hypertext Archive of the Tropics Amos Tutuola (1920-1997), The Palm-Wine Drinkard (1952) 